\title{
Saindo da adolescência com a vida (dos outros) nas mãos: estudo sobre a formação ética dos
} estudantes de Medicina

Leaving adolescence behind with the life (of others) in one's hands: a study on the ethical training of medical students

Esta tese consiste em um estudo sobre a formação ética dos estudantes de Medicina no Brasil. Inicia-se com uma revisão histórica da educação médica no Brasil e no mundo, procurando situar o leitor não familiarizado com o nosso campo de pesquisas, apresentando e discutindo, brevemente, o modelo de ensino hegemônico $e$ as novas tendências que se apresentam neste campo.

Em seguida, é apresentado um panorama crítico das teorias que buscam explicar o processo de conformação da moral individual, desde as teorias de socialização $e$ aprendizagem social, até as novas abordagens $e$ interpretações da teoria cognitivista do desenvolvimento moral de Piaget/Kohlberg.

Adotando-se criticamente a abordagem cognitivista, são apresentadas algumas novas contribuições para explicar o processo cognitivo de desenvolvimento moral, bem como se estabelece o diálogo crítico com outros autores contemporâneos.

É apresentado um estudo com estudantes de Medicina de diferentes faculdades no qual são identificadas as situações que os estudantes reconhecem como envolvendo uma decisão de ordem ética e que são analisadas. Conclui-se que o processo de ensino em Medicina, ao objetificar o ser humano como objeto de trabalho e de ensino, deixa de considerá-lo como um sujeito moral. Finalmente, defende-se o ensino da ética aplicada como disciplina na graduação, inserida no ensino das humanidades médicas, apontando para a possibilidade de, no futuro, estabelecer seu ensino transversalmente.

\section{Sergio Tavares de Almeida Rego \\ Tese de Doutorado, 2001 Instituto de Medicina Social Universidade Estadual do Rio de Janeiro}

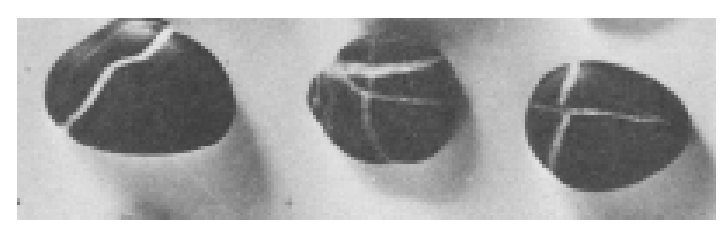

PALAVRAS-CHAVE: formação médica; ética. KEYWORDS: medical education; ethics. PALABRAS CLAVE: formación medica; etica.

Recebido para publicação em: 22/05/01. Aprovado para publicação em: 07/06/01. 